\title{
MENCIPTA SASTRA ANAK BERTEMA KEARIFAN LOKAL BERBASIS PENDIDIKAN KARAKTER
}

\author{
Rina Ratih \\ Universitas Ahmad Dahlan \\ J1. Kapas No. 9, Semaki, Kec. Umbulharjo, Kota Yogyakarta \\ email: rinaratihuad@yahoo.com
}

\begin{abstract}
The concepts of local wisdom inherited through folklores and children literature are the strategies to transform the values considered important to learn by children through textbooks. Therefore, children literature should be meaningful and highly relevant to the empowerment of the children's life according to the stage of their development. This study questions how to write children's literature with the theme of local wisdom based on character education. Based on the problem, the study aims to produce children literature with the theme of local wisdom, which is based on character education and according to the children's development. There are three stages of children literature: emotional, intellectual, and personal development. The study belongs to descriptive qualitative research, employing Brady's theory on children development and Rampan's on the technique of writing children literature. Library research and creative process are used in the method. The study generates three models of folklore with the theme of local wisdom according to the children development: Putri Emas dan Burung Ajaib, Putri Cantik dari Pulau Bintan, and Sang Pembangkang. Besides, it also produces three literary works based on character education: "Lalang dan Kupu-Kupu yang Menawan," "Gara-gara Ketinggalan Bekal," and "Surti, Mawar, and Kupu-kupu."
\end{abstract}

Keywords: children literature, local wisdom, character education

\section{PENDAHULUAN}

Sastra anak-anak termasuk di dalamnya cerita anak-anak adalah cerita yang ditulis untuk anak-anak, yang berbicara mengenai kehidupan anak-anak dan sekeliling yang mempengaruhi anak-anak, dan tulisan itu hanya dapat dinikmati oleh anak-anak dengan bantuan dan pengarahan orang dewasa (Sarumpaet, 2003:108). Sejalan dengan Sarumpaet, Norton (1993) mengemukakan bahwa sastra anak adalah sastra yang mencerminkan perasaan dan pengalaman anak-anak melalui pandangan anak-anak. Buku bacaan anak-anak mudah ditemukan di berbagai toko buku. Topik sastra anak pun sudah banyak yang menyoroti dan bahkan melakukan penelitian.

Penelitian tentang cerita anak telah dilakukan di antaranya oleh Munandar dkk. (2018) tentang cerita anak yang berbasis kearifan lokal Mendong di Kota Tasikmalaya, Jawa Barat. Munandar juga telah melakukan uji kelayakan produk hasil penelitiannya yang digunakan sebagai sumber bacaan ataupun bahan ajar di Sekolah Dasar. Penelitian lain dilakukan oleh Rifki tentang integrasi pendidikan karakter dalam pembelajaran IPS di Sekolah Dasar. Menurut Rifki Afandi 
(2011), permasalahan yang dialami bangsa ini begitu memprihatinkan terutama di kalangan anak dan remaja sebagai penerus bangsa, dengan pendidikan karakter melalui pembelajaran IPS diharapkan bisa menyelesaikan permasalahan yang dialami bangsa Indonesia saat ini. IPS sebagai bidang studi dalam pembelajaran yang bertujuan agar peserta didik mampu bertanggung jawab terhadap kehidupan masyarakat, bangsa, dan negara dapat diimplementasikan dengan memasukkan nilai-nilai yang terkandung dalam pendidikan karakter.

Penelitian Munandar dan Rifki berbeda dengan tulisan ini. Munandar menguji buku produk penelitiannya sebagai bahan ajar di Sekolah Dasar. Rifki membahas integrasi pendidikan karakter dalam pembelajaran IPS di Sekolah Dasar. Keduanya memiliki kesamaan membahas kearifan lokal dalam cerita anak dan kontribusi hasil penelitiannya sebagai bahan ajar, sedangkan tulisan ini menghasilkan model cerita anak bertema kearifan lokal, berbasis pendidikan karakter, serta sesuai tahapan perkembangan jiwa anak.

Sejumlah peneliti mengemukakan bahwa kearifan tidak dapat ditransfer, tetapi kearifan dapat dikembangkan sebagai karakter peserta didik melalui model dan ketersediaan lingkungan yang kondusif. Dalam bukuTeaching for Wisdom Through History: Infusing Wise Thingking Skills in the School Curriculum, Peneliti Sternberg, Jarvin dan Reznitskaya (dalam Ferrari dan Potworowski, Ed., 2008) menyatakan bahwa sekolah dapat membantu mengembangkan kearifan.Konsepsikonsepsi kearifan lokal yang diwariskan secara turun temurun melalui dongeng, legenda, petuahpetuah adat merupakan strategi transformasi nilai-nilai yang dipandang penting untuk dimiliki anak. Oleh karena itu, materi pembelajaran harus memiliki makna dan relevansi tinggi terhadap pemberdayaan hidup mereka secara nyata.

Pendapat Sternberg menyatakan bahwa konsepsi kearifan lokal yang diturunkan melalui dongeng, legenda, dan petuah-petuah sangat penting. Nilai-nilai kearifan lokal itu dibutuhkan anak dalam proses pembentukan karakternya. Hal itu sejalan dengan tujuan pendidikan nasional. Pasal I Undang-Undang Sidiknas tahun 2003 menyatakan bahwa tujuan pendidikan nasional adalah mengembangkan potensi peserta didik untuk memiliki kecerdasan, kepribadian dan akhlak mulia. Pesan dari Undang-Undang Sidiknas tahun 2003 tersebut jelas agar pendidikan tidak hanya membentuk insan Indonesia yang pandai, tetapi juga memiliki kepribadian atau berkarakter. Harapannyaakan lahir generasi yang tidak hanya memiliki kemampuan aspek pengetahuan yang baik, tetapi juga memiliki generasi yang moralnya baik dan nilai-nilai luhur bangsa serta beragama. Dengan demikian perlu kiranya, model-model cerita-cerita anak memuat nilai kearifan lokal 
sekaligus berbasis pendidikan karakter. Hal lain yang perlu diperhatikan adalah cerita-cerita yang diajarkan/dibaca oleh anak sesuai dengan tahapan perkembangan jiwanya.

Cerita anak yang mengandung kearifan lokal dan berbasis pendidikan karakter sudah cukup banyak tersedia di berbagai toko buku. Para peneliti pun sudah menganalisis buku-buku tersebut. Akan tetapi, masih langka penelitian yangberfokus pada penciptaan cerita anak yang bertema kearifan lokal dan berbasis pendidikan karakter. Hal ini dapat dipahami karena tidak banyak penulis cerita yang sekaligus menjadi peneliti. Rina Ratih (2016) membahas proses kreatif penulisan cerita anak, fabel, dan cerita rakyat serta berbagai kesulitan yang dihadapi oleh penulis pemula. Menurut Ratih, menulis adalah proses kematangan pengalaman imajinal, emosional, dan intelektual penulisnya. Menulis cerita anak, fabel, atau menulis ulang cerita rakyat adalah komitmen dan kecintaan seseorang pada sastra anak. Adapun yang perlu dikuasai oleh seorang penulis; pertama, menguasai teknik penulisan, eyd, kosa kata dll; kedua, membaca karya orang lain sebagai referensi; dan ketiga, praktik menulis secara terus-menerus dan tidak mudah berputus asa.

Berdasarkan permasalahan di atas, tulisan ini bertujuan menghasilkan model bacaan cerita anak yang bertema kearifan lokal, berbasis pendidikan karakter, dan sesuai dengan tahapan perkembangan jiwa anak. Teori yang digunakan adalah teori Brady tentang tahapan perkembangan jiwa anak dan teknik penulisan cerita anak Rampan. Ada tiga tahapan perkembangan jiwa anak, yaitu perkembangan emosional, intelektual, dan personal.Tulisan ini diharapkan memberi kontribusi positif berupa bahan bacaan bagi anak sesuai tahap perkembangan jiwanya.

\section{METODE}

Kearifan lokal merupakan semua bentuk pengetahuan, keyakinan, pemahaman atau wawasan, serta adat kebiasaan atau etika yang menuntun perilaku manusia dalam kehidupan di dalam komunitas ekologis (Keraf, 2010:369). Jadi, kearifan lokal itu bukan hanya menyangkut pengetahuan dan pemahaman masyarakat adat tentang manusia dan bagaimana relasi yang baik di antara manusia, melainkan juga menyangkut pengetahuan, pemahaman, adat kebiasaan tentang manusia, alam, dan bagaimana relasi di antara semua penghuni komunitas ekologis itu harus dibangun.

Menurut Rahyono (2009), kearifan lokal merupakan kecerdasan manusia yang dimiliki oleh kelompok etnis tertentu yang diperoleh melalui pengalaman masyarakat. Artinya, kearifan lokal adalah hasil dari masyarakat tertentu melalui pengalaman mereka dan belum tentu dialami oleh masyarakat yang lain. Nilai- nilai tersebut akan melekat sangat kuat pada masyarakat tertentu dan 
nilai itu sudah melalui perjalanan waktu yang panjang, sepanjang keberadaan masyarakat tersebut. Sedangkan menurut Ujianto (2013:59)kearifan lokal merupakan potensi lokal yang perlu untuk dipertahankan dan dikelola secara bijaksana. Mengkaji dan mempelajari tentang kearifan lokal merupakan upaya untuk mempertahankan nilai- nilai budaya yang telah menjadi kebiasaan atau adat istiadat pada suatu kelompok masyarakat atau daerah. Mempertahankan nilai budaya tersebut dilakukan agar kearifan lokal yang ada tidak pudar dan dapat dinikmati serta memberi kemanfaatan bagi generasi berikutnya.

Pendidikan karakter dapat dimaknai sebagai pendidikan budi pekerti yaitu yang melibatkan aspek pengetahuan (cognitive), sikap perasaan (affection felling), dan tindakan. Karakter yang baik menurut Aristoteles sebagai “...the life of right conduct-right conduct in relation to other persons and in relation to oneself'. Karakter dapat dimaknai sebagai kehidupan berperilaku baik, yakni berperilaku baik terhadap pihak lain dan terhadap diri sendiri. Dasar pendidikan karakter ini sebaiknya mulai diterapkan sejak anak usia dini.Pendidikan karakter adalah suatu sistem pendidikan dengan penanaman nilai-nilai sesuai dengan budaya bangsa dengan komponen aspek pengetahuan (cognitive), sikap perasaan (affection felling), dan tindakan, baik terhadap Tuhan Yang Maha Esa (YME), diri sendiri, masyarakat maupun bangsanya. Cerita anak yang berbasis pendidikan karakter sudah sering dibahas oleh para peneliti. Akan tetapi, proses kreatif penulisan cerita anak yang bertema kearifan lokal dan cerita anak yang berbasis pada pendidikan karakter masih kurang mendapat perhatian para peneliti. Hal ini terjadi karena para peneliti melakukan analisis terhadap cerita anak yang sudah ada, sedangkan proses kreatif penulisan diserahkan sepenuhnya kepada para penulis yang notabene bukan peneliti.

Anak dan bacaan anak hendaknya selaras karena secara universal perkembangan berbagai aspek kejiwaan anak sesuai dengan tingkat usianya yang pasti akan melewati tahap-tahap tertentu. Menurut Brady (dalam Saxby \& Winch, 1991:26) tahapan dan karakteristik perkembangan kejiwaan anak meliputi aspek berpikir, bahasa, personalitas, moral, dan pertanyaan-pertanyaan terkait yang dapat membantu dalam seleksi bacaan sastra. Di pihak lain, menurut Huck dkk. (1987:52), di samping aspek-aspek yang dikemukakan Brady, perkembangan itu juga melibatkan aspek fisik dan pertumbuhan konsep cerita.

Dasar pemikiran pengujian tahapan perkembangan anak ada empat. Menurut Brady, (dalam Saxby \& Winch, 1991:26-27)pertama; pertimbangan ketertarikan anak terhadap suatu bacaan;kedua, pemahaman terhadap perkembangan anak secara umum dan khusus;ketiga, pemahaman terhadap tahapan perkembangan anak akan membantu dalam seleksi bacaan; 
dankeempat, pemahaman kesesuaian dalam pemilihan bacaan dengan tahapan perkembangan anak perlu diperluas dengan mencakup kontribusi tiap tahapan itu.

Setiap tahapan perkembangan kejiwaan anak memiliki karakteristik yang berbeda. Adapun tahapan-tahapan perkembangannya meliputi perkembangan intelektual, moral, emosional dan personal, bahasa, dan pertumbuhan konsep cerita (Brady, 1991:28-37; Huck dkk, 1987:52-63). Tiap tahapan mempunyai karakteristik yang berbeda, walau tidak dalam pengertian bertentangan, sejalan dengan perkembangan tingkat kematangan anak. Hal itu akan membawa konsekuensi logis pada adanya karakteristik yang juga berbeda dengan bacaan yang dinyatakan sesuai (matching) dengan tiap tahapan yang dimaksud.

Anak Sekolah Dasar adalah masa anak berada pada tahap operasional the concrete operational, 7-11 tahun). Pada tahap ini anak mulai dapat memahami logika secara stabil. Karakteristik anak pada tahap ini antara lain adalah (1) anak dapat mengklasifikasikan objek berdasarkan sifat-sifat umum, (2) Anak dapat membuat urutan sesuatu sebagaimana mestinya, menurutkan abjad, angka, besar-kecil, (3) Anak mulai dapat mengembangkan imajinasinya ke masa lalu dan masa depan, dan (4) Anak mulai dapat berpikir argumentatif dan memecahkan masalah sederhana, ada kecenderungan memperoleh ide-ide sebagaimana yang dilakukan orang dewasa, namun belum dapat berpikir tentang sesuatu yang abstrak karena jalan berpikirnya masih terbatas pada situasi yang konkret.

Kemungkinan implikasi terhadap buku bacaan sastra yang sesuai dengan karakteristik pada tahap perkembangan intelektual di atas antara lain adalah buku-buku bacaan yang memiliki karakteristik sebagai berikut: (a) buku-buku bacaan narasi atau eksplanasi yang mengandung urutan logis dari yang sederhana ke yang lebih kompleks, (b) buku-buku bacaan yang menampilkan cerita yang sederhana baik yang menyangkut masalah yang dikisahkan, cara pengisahan, maupun jumlah tokoh yang dilibatkan, (c) buku-buku bacaan yang menampilkan berbagai objek gambar secara bervariasi, bahkan mungkin yang dalam bentuk diagram dan model sederhana, dan (d) buku-buku bacaan narasi yang menampilkan narator yang mengisahkan cerita, atau cerita yang dapat membawa anak untuk memproyeksikan dirinya ke waktu atau tempat lain. Dalam masa ini anak sudah dapat terlibat memikirkan dan memecahkan persoalan yang dihadapi tokoh protagonis atau memprediksikan kelanjutan cerita.

Anak usia Sekolah Menengah Pertama (SMP) masuk pada tahap operasi formal (the formal operational, 11 atau 12 tahun ke atas). Pada tahap ini, tahap awal adolesen, anak sudah mampu berpikir abstrak. Karakteristik penting dalam tahap ini antara lain adalah (1) anak sudah mampu 
berpikir "secara ilmiah", berpikir teoretis, berargumentasi dan menguji hipotesis yang mengutamakan kemampuan berpikir, (2) Anak sudah mampu memecahkan masalah secara logis dengan melibatkan berbagai masalah yang terkait. Adapun implikasi terhadap pemilihan buku bacaan sastra anak adalah (a) buku-buku bacaan cerita yang menampilkan masalah yang membawa anak untuk mencari dan menemukan hubungan sebab akibat serta implikasi terhadap karakter tokoh; (b) buku-buku bacaan cerita yang menampilkan alur cerita ganda, alur cerita yang mengandung plot dan subplot, yang dapat membawa anak untuk memahami hubungan antarsubplot tersebut, serta yang menampilkan persoalan (atau konflik) dan karakter yang lebih kompleks.

Kedua tahapan perkembangan jiwa anak di atas sangat penting diketahui agar dapat diintegrasikan pada proses penciptaan.Cerita anak yang baik berbicara tentang kehidupan anak. Dalam tulisan berjudul "Dasar-Dasar Penulisan Cerita Anak", Rampan (2003:89) menjelaskan bahwa cerita anak adalah cerita sederhana yang kompleks. Kesederhanaan itu ditandai oleh syarat wacananya yang baku dan berkualitas tinggi, namun tidak ruwet sehingga komunikatif. Di samping itu, pengalihan pola pikir orang dewasa kepada dunia anak-anak dan keberadaan jiwa dan sifat anak-anak menjadi syarat cerita anak-anak yang digemari. Dengan kata lain, cerita anak-anak harus berbicara tentang kehidupan anak-anak dengan segala aspek yang berada dan mempengaruhi mereka.

Berdasarkan konsep dasar-dasar penulisan cerita anak Rampan, maka (1)dipilihcerita rakyat dari Aceh, Riau, dan Jawa yang bertema kearifan lokal tetapi masih berupa sinopsis. Selanjutnya dijelaskan proses kreatif pengembangan cerita dari sinopsis menjadi sebuah cerita (buku) yang layak baca untuk anak; dan (2) dijelaskan proses kreatif penulisan cerita anak yang bermula dari ide dan imajinasi. Cerita tersebut berbasis pendidikan karakter. Cerita rakyat yang dikembangkan dari sinopsis dan cerita anak yang berdasarkan ide dan imajinasi berpegang teguh pada tahapan perkembangan jiwa anak.

\section{PEMBAHASAN}

\section{Proses Kreatif Penulisan Cerita Anak Bertema Kearifan lokal}

Menulis atau mencipta cerita anak membutuhkan keterampilan dan pengalaman. Di samping itu, perlu memiliki wawasan dan pengetahuan terutama tahapan perkembangan jiwa anak. Mengapa? Anak-anak perlu bacaan yang memiliki karakteristik sesuai tahap perkembangan jiwanya. Dari tahapan perkembangan: intelektual, moral, emosional dan personal, bahasa, dan 
pertumbuhan konsep cerita, seperti yang dikemukakan di atas.Tidak boleh dilupakan hal yang sangat penting yaitu perkembangan intelektual, emosional dan personal.

Seorang penulis cerita anak harus memahami alasannya mengapa perlu mengetahui tahapan perkembangan jiwa anak karena dalam diri anak secara terus menerus berproses agar dirinya secara penuh berfungsi menjadi sebagai person (fully functioning) atau dapat menjadi person yang dapat mengaktualisasikan diri (becoming). Untuk mencapai itu semua, kebutuhan dasarnya harus terpenuhi, yaitu kesadaran bahwa dirinya merasa dicintai dan dapat mencintai, dimengerti, aman dan selamat, diakui sebagai anggota kelompok, dan merasa memiliki kebebasan untuk tumbuh dan berkembang. Hal-hal tersebut di atas, salah satunya dapat ditemukan pada cerita rakyat.

Cerita rakyat yang sarat dengan muatan kearifan lokal masih banyak beredar di masyarakat dan belum terdokumentasikan. Oleh karena itu, perlu 'turun tangan'seorang penulis melalui proses kreatifnya melakukan'penulisan ulang' cerita rakyat, seperti yang telah dilakukan oleh peneliti terhadap 3 cerita rakyat dari Riau, Aceh, dan Jawa Timur berikut ini.Adapun proses kreatif 'penulisan ulang' cerita rakyat dilakukan sebagai berikut: (1) membuat sinopsis cerita rakyat dari narasumber yang dapat dipercaya, (2) membuat kerangka karangan sesuai sinopsis, (3) mengembangkan setiap kerangka karangan menjadi deskripsi tanpa mengubah alur cerita, (4) mengembangkan tokoh, alur, dan latar, (5) menggunakan kekuatan imajinasi untuk menyusun dialog sebagai penguatan karakter, (6) menciptakan klimaks sebagai daya tarik dan puncak cerita, dan (7) mengakhiricerita sesuai aslinya.

Tabel 1: Proses Kreatif Penulisan Ulang Cerita Rakyat yang Bertema Kearifan Lokal

\begin{tabular}{|c|c|c|}
\hline Judul Asli & Judul Buku & Kerangka karangan yang digunakan untuk pengembangan alur \\
\hline $\begin{array}{l}\text { Nakhoda } \\
\text { Lancang } \\
\text { (Riau) }\end{array}$ & $\begin{array}{l}\text { Putri Cantik } \\
\text { dari Pulau } \\
\text { Bintan } \\
\text { (Pustaka } \\
\text { Pelajar, 2014, } \\
122 \text { halaman) }\end{array}$ & $\begin{array}{l}\text { 1. Mencari Jodoh Sang Putri } \\
\text { 2. Si Mikin Mancang Gelanggang } \\
\text { 3. Putri Retno Intan Diusir dari Istana } \\
\text { 4. Pertunangan Putri Sahilan } \\
\text { 5. Singgah di Pulau Bintan } \\
\text { 6. Terpikat Kecantikan Putri Raja } \\
\text { 7. Memanah Burung Nuri di Rimba larangan } \\
\text { 8. Siasat Putri Indun Suri } \\
\text { 9. Menjadi Burung Punai }\end{array}$ \\
\hline $\begin{array}{l}\text { Syah } \\
\text { Keubandi } \\
\text { dan Putri } \\
\text { Berjambul } \\
\text { Emas } \\
\text { (Aceh) }\end{array}$ & $\begin{array}{l}\text { Puteri Emas } \\
\text { dan Burung } \\
\text { Ajaib } \\
\text { (Pustaka } \\
\text { Pelajar, 2013, }\end{array}$ & $\begin{array}{l}\text { 1. Suami Istri Raksasa Menemukan Seratus Bayi } \\
\text { 2. Putri Ajaib menolong Putri Berjambul Emas } \\
\text { 3. Permaisuri Raja Hamsoikasa yang Iri hati } \\
\text { 4. Petunjuk Burung Ajaib } \\
\text { 5. Putri Berjambul Emas di Tangan Jin Siblah Abin } \\
\text { 6. Putri Emas Meloloskan diri } \\
\text { 7. Diundang Baginda Hamsoikasa ke Istana }\end{array}$ \\
\hline
\end{tabular}




\begin{tabular}{|c|c|c|}
\hline & 105 halaman) & 8. Syah Keubandi Bertemu Putri Berjambul Emas \\
\hline $\begin{array}{l}\text { Batara } \\
\text { Katong } \\
\text { (Jawa } \\
\text { Timur) }\end{array}$ & $\begin{array}{l}\text { Sang } \\
\text { Pembangkang } \\
\text { (Pustaka } \\
\text { pelajar, 2011, } \\
83 \text { halaman) }\end{array}$ & $\begin{array}{l}\text { 1. Kerajaan Wengker di Ponorogo } \\
\text { 2. Prajurit Pilih Tanding Kerajaan Wengker } \\
\text { 3. Kerajaan Majapahit Menyerang Kerajaan Wengker } \\
\text { 4. Rahasia Kemenangan Kerajaan Wengker } \\
\text { 5. Batara Katong Mendapat Tugas Rahasia dari Baginda Raja } \\
\text { 6. Batara Katong Menikah dengan Putri Kerajaan Wengker } \\
\text { 7. Batara Katong Berhasil Merebut Keris Eyang Puspitarini } \\
\text { 8. Ki Ageng Putu Surya Alam Berlutut di hadapan Batara Katong } \\
\text { 9. Kerajaan Wengker Bersatu Kembali dengan Kerajaan } \\
\text { Majapahit }\end{array}$ \\
\hline
\end{tabular}
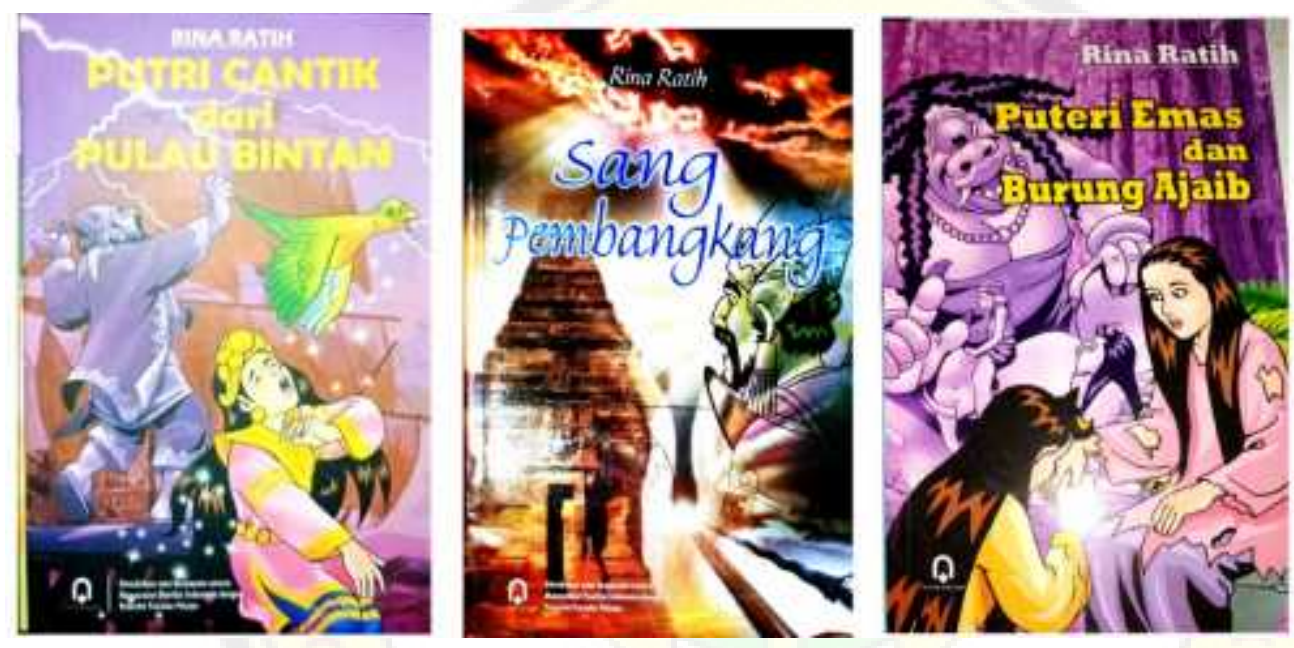

Cerita rakyat di atas, baik dari Aceh, Riau, maupun dari Jawa, ketiganya mengandung kearifan lokalberupa pengetahuan lokal, keterampilan lokal, kecerdasan lokal, sumber daya lokal, proses sosial lokal, norma-etika lokal, dan adat-istiadat lokal. Petuah-petuah yang penuh dengan nilai-nilai kehidupan terdapat di dalamnya sesuai dengan adat istiadat yang berlaku. Baginda raja yang arif bijaksana. Kehidupan masyarakat yang religius. Kekuatan manusia dan 'dunia lain'. Kejujuran dalam berdagang. Rasa hormat prajurit kepada Baginda Raja. Sikap sopan santun yang diperlihatkan perempuan/masyarakat kepada keluarga Baginda Raja. Adat istiadat yang masih kuat dijaga, baik oleh Raja maupun oleh masyarakat pada zamannya. Masyarakat yang menjaga alam dan lingkungan agar tetap penuh sinergi. Upaya-upaya damai untuk menghindari perpecahan dan perang antarsaudara, dan masih banyak kearifan lokal lainnya pada ketiga cerita rakyat tersebut. Sebagaimana yang dinyatakan Sibarani (2015) bahwa kearifan lokal adalah pengetahuan asli (indigineous knowledge) atau kecerdasan lokal (local genius) suatu masyarakat yang berasal dari nilai luhur tradisi budaya untuk mengatur tatanan kehidupan masyarakat dalam rangka mencapai 
kemajuan komunitas, baik dalam penciptaan kedamaian maupun peningkatan kesejahteraan masyarakat.

Ketiga cerita rakyat di atas sangat tepat untuk anakpada tahap operasi formal (the formal operational, 11 atau 12 tahun ke atas). Pada tahap ini, tahap awal adolesen, anak sudah mampu berpikir abstrak. Karakteristik penting dalam tahap ini antara lain adalah anak sudah mampu berpikir "secara ilmiah", berpikir teoretis, berargumentasi dan menguji hipotesis yang mengutamakan kemampuan berpikir. Anak juga sudah mampu memecahkan masalah secara logis dengan melibatkan berbagai masalah yang terkait. Anak seusia SMP ini sudah mulai tertarik pada cerita yang mengajak anak berpikir untuk mencari dan menemukan hubungan sebab akibat serta implikasinya terhadap karakter, seperti pada tokoh Batara Katong dan Nakhoda Lancang.

Anak pada tahap usia ini tertarik dengan cerita cerita yang penuh petualang dan beralur ganda bahkan alur flashback atau backtracking. Mereka mulai menyukai cerita yang sarat konflik seperti pada ketiga cerita rakyat Putri Emas dan Burung Ajaib, Putri Cantik dari Pulau Bintan, dan Sang Pembangkang.Bacaan seperti itu mampu memenuhi perkembangan jiwa anak, seperti perkembangan intelektual, moral, emosional dan personal, bahasa, dan pertumbuhan konsep cerita.

\section{Proses Kreatif Penulisan Cerita Anak Berbasis Pendidikan karakter}

Menulis cerita anak yang berasal dari ide dan imajinasi berbeda dengan menulis ulang cerita rakyat. Bagi penulis pemula, menulis cerita anak perlu strategi. Meskipun sudah memiliki ide tetapi jika tidak menguasai keterampilan menulis, EYD, menciptakan dialog, mengembangkan alur dan latar, menguatkan watak tokoh melalui perilaku, dan menciptakan klimaks, maka cerita tidak akan terwujud. Cerita anak yang ditulis pun harus dilengkapi dengan pesan, baik tersirat maupun tersurat agar nilai-nilai kehidupan yang berbasis pada pendidikan karakter termuat di dalamnya. Berikut cerita anak yang berasal dari ide kemudian dikembangkan menjadi cerita dipenuhi dengan nilai pendidikan karakter yang sesuai tahap perkembangan jiwa anak.

Tabel 1: Proses Kreatif Penulisan Cerita Anak yang Bertema Kearifan Lokal

\begin{tabular}{|c|c|c|}
\hline Judul Cerita & Ide Cerita & $\begin{array}{l}\text { Nilai Pendidikan } \\
\text { Karakter }\end{array}$ \\
\hline $\begin{array}{l}\text { "Lalang dan } \\
\text { Kupu- Kupu yang } \\
\text { Menawan" } \\
\text { dalam buku } \\
\text { Lebah Lebay di } \\
\text { Taman Larangan } \\
\text { (Pustaka Pelajar, } \\
\text { April 2015) }\end{array}$ & $\begin{array}{l}\text { Seekor belalang yang iri hati melihat kupu-kupu karena } \\
\text { bersayap indah dan dapat terbang sesuka hati. } \\
\text { Diingatkan oleh induknya bahwa sifat iri itu tidak baik. } \\
\text { Akibat satu peristiwa, si belalang akhirnya sadar bahwa } \\
\text { setiap makhluk diciptakan Allah dengan segala } \\
\text { kelebihan dan kekurangannya. Jadi tidak perlu ingin } \\
\text { menjadi atau seperti orang lain tetapi hendaknya hidup } \\
\text { itu selalu dihadapi dengan rasa syukur. }\end{array}$ & $\begin{array}{l}\text { Jujur, } \\
\text { toleransi, } \\
\text { rasa ingin } \\
\text { tahu, } \\
\text { komunikatif, } \\
\text { cinta damai, } \\
\text { peduli } \\
\text { lingkungan, }\end{array}$ \\
\hline
\end{tabular}




\begin{tabular}{|c|c|c|}
\hline & & peduli sosial. \\
\hline $\begin{array}{l}\text { "Gara- Gara Bekal } \\
\text { Ketinggalan" } \\
\text { dalam buku } \\
\text { Belalang Sembah } \\
\text { dan Putri Lala } \\
\text { (Azzagrafika, } \\
\text { April 2017) }\end{array}$ & $\begin{array}{l}\text { Setiap pagi, Anisa membawa bekal nasi ke sekolah } \\
\text { untuk makan saat istirahat siang. Suatu hari Anisa } \\
\text { ketinggalan bekal. Mira teman baru di kelas mengajak } \\
\text { makan di kantin sekolah. Mira tidak pernah membawa } \\
\text { bekal karena ibunya sakit-sakitan. Karena enak, Anisa } \\
\text { jadi ketagihan jajan soto di kantin dengan sambal } \\
\text { pedasnya. Akibatnya Anisa sakit dan tidak masuk } \\
\text { sekolah beberapa hari. Mira ditemani ayahnya } \\
\text { menjenguk Anisa. Ia minta maaf. Ibu jadi mengetahui } \\
\text { masalahnya. Demi kesehatan dan kebaikan bersama, } \\
\text { akhirnya Ayah Mira memesan bekal makan kepada ibu } \\
\text { Anisa. }\end{array}$ & $\begin{array}{l}\text { Jujur, } \\
\text { disiplin, } \\
\text { kerja keras, } \\
\text { kreatif, } \\
\text { mandiri, } \\
\text { komunikatif, } \\
\text { peduli } \\
\text { lingkungan, } \\
\text { peduli sosial, } \\
\text { tanggung } \\
\text { jawab }\end{array}$ \\
\hline $\begin{array}{l}\text { "Surti, Mawar, } \\
\text { dan Kupu- Kupu" } \\
\text { dalam buku Surti, } \\
\text { Mawar, dan } \\
\text { Kupu-Kupu } \\
\text { (Buana Grafika, } \\
\text { April 2018) }\end{array}$ & $\begin{array}{l}\text { Surti ingin melihat kupu-kupu di kebun kecilnya. Ibu } \\
\text { meminta Surti rajin merawat bunga-bunga agar nanti } \\
\text { kupu-kupu datang sendiri. Surti rajin membersihkan } \\
\text { rumput, menyiram tiap pagi dan sore, dan memberinya } \\
\text { pupuk. Sampai akhirnya, bunga mawar, melati, dan } \\
\text { bunga lainnya mekar berwarna-warni. Kupu-kupu pun } \\
\text { datang beterbangan setiap hari ke kebun kecilnya. }\end{array}$ & $\begin{array}{l}\text { Disiplin, } \\
\text { kerja keras, } \\
\text { rasa ingin } \\
\text { tahu, } \\
\text { komunikatif, } \\
\text { peduli } \\
\text { lingkungan, } \\
\text { tanggung } \\
\text { jawab }\end{array}$ \\
\hline
\end{tabular}
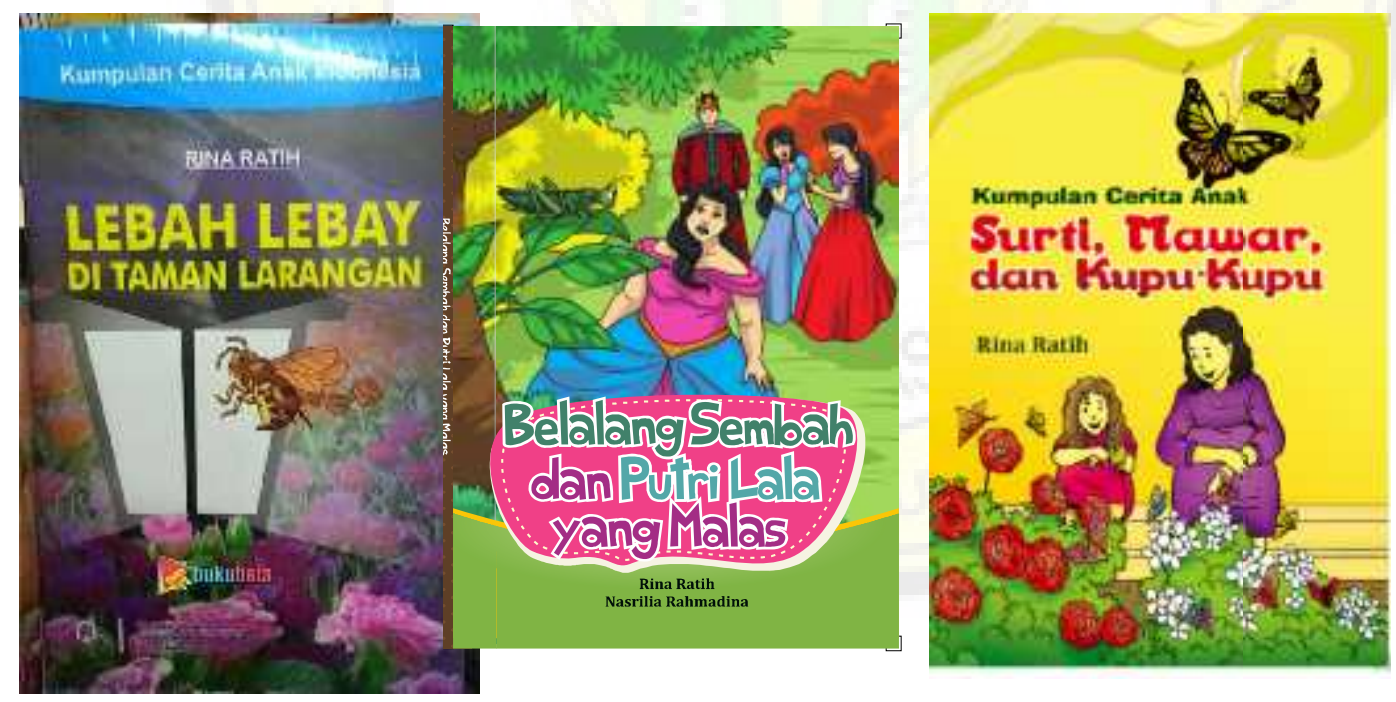

Dari tabel di atas, tampak nilai-nilai pendidikan karakter yang terdapat pada ketiga cerita tersebut. Makna karakter dikemukakan oleh Thomas Lickona (1991) “A reliable inner disposition to respon to situations in a morally good way". Dari pengertian di atas dapat dipahami bahwa karakter identik dengan akhlak, sehingga karakter merupakan nilai-nilai perilaku manusia yang universal dan meliputi seluruh aktivitas manusia, baik dalam rangka berhubungan dengan 
Tuhannya, dengan dirinya, dengan sesama manusia, maupun dengan lingkungannya, yang terwujud dalam pikiran, sikap, perasaan, perkataan, dan perbuatan berdasarkan norma-norma agama, hukum, tata krama, budaya, dan adat istiadat.

Cerita anak di atas tepat sebagai bacaan anak usia SD. Anak SD kelas 4-6 atau usia 10-12 tahun, fungsi tahap operasional konkret dapat melihat hubungan yang lebih abstrak; pengalaman pada tahap kepandaian versus perasaan rendah diri; penerimaan masalah benar berdasarkan kefairan; memiliki ketertarikan yang kuat dalam aktivitas sosial, meningkatnya minat pada kelompok, mencari kekariban dalam kelompok; mulai mengadopsi model kepada orang lain daripada ke orang tua; menunjukkan minatnya pada aktivitas khusus; mencari persetujuan dan ingin mengesankan; menunjukkan kemampuan dan kemauan untuk melihat sudut pandang orang lain; pencarian nilai-nilai; menunjukkan adanya perbedaan di antara individu; mempunyai citarasa keadilan dan peduli kepada orang lain; dan pemahaman serta penerimaan terhadap adanya aturan berdasarkan perbedaan jenis kelamin.

Pada tahap ini, anak sudah mampu berpikir abstrak, mampu berpikir "secara ilmiah", berpikir teoretis, berargumentasi dan menguji hipotesis yang mengutamakan kemampuan berpikir. Anak juga sudah mampu memecahkan masalah secara logis dengan melibatkan berbagai masalah yang terkait. Seperti Anisa dan Mira pada cerita 'Gara- Gara Ketinggalan Bekal” yang akhirnya mampu menyelesaikan permasalahan di antara mereka dan mencari kekariban dalam kelompok serta peduli pada orang lain. Pencarian nilai-nilai dan kesadaran adanya perbedaan individu tampak pada cerita "Lalang dan Kupu-Kupu yang Menawan". Sedangkan pencarian nilai-nilai dan menunjukkan kemampuan dan kemauan serta menunjukkan minat pada aspek khusus tampak kuat pada cerita "Surti, Mawar, dan Kupu-Kupu". Ketiga cerita di atas telah memenuhi kebutuhan anak karena sesuai dengan tahapan perkembangan yang meliputi perkembangan intelektual, moral, emosional dan personal, bahasa, dan pertumbuhan konsep cerita.

\section{SIMPULAN}

Cerita anak sebaiknya ditulis memperhatikan tahap perkembangan jiwa anak. Cerita yang tepat untuk anak adalah cerita yang sarat dengan kearifan lokal dan berbasis pendidikan karakter karena "A reliable inner disposition to respon to situations in a morally good way". Cerita rakyat tepat menjadi bacaan bagi anak usia SMP karena pada tahap ini anak sudah mampu berpikir "secara ilmiah", berpikir teoretis, berargumentasi dan menguji hipotesis yang mengutamakan kemampuan berpikir, mampu memecahkan masalah secara logis dengan melibatkan berbagai masalah yang 
terkait, sebagaimana cerita rakyat berjudul Putri Emas dan Burung Ajaib (Aceh), Putri Cantik dari Pulau Bintan (Riau), dan Sang Pembangkang (Jawa Timur).

Cerita anak yang tepat untuk anak usia SD dapat diciptakan dengan memperhatikan kearifan lokal dan berbasis pendidikan karakter karena pada tahap perkembangan jiwa inianak mulai dapat memahami logika secara stabil, dapat mengklasifikasikan objek, membuat urutan, mengembangkan imajinasinya ke masa lalu dan masa depan, mulai dapat berpikir argumentatif dan memecahkan masalah sederhanasebagaimana cerita anak berjudul 'Lalang dan Kupu- Kupu yang Menawan”, “Gara- Gara Ketinggalan Bekal', dan "Surti, Mawar, dan Kupu- Kupu” yang berbasis pendidikan karakter. Baik Cerita rakyat, maupun cerita anak sudah memenuhi tiga tahapan perkembangan jiwa anak yaitu perkembangan emosional, intelektual, dan personal.

\section{DAFTAR RUJUKAN}

Afandi, R. 2011. "Integrasi Pendidikan Karakter dalam Pembelajaran IPS di Sekolah Dasar" dalam PEDAGOGIA Vol. 1, No. 1, Desember 2011: 85-98

Munandar, A. dkk. 2018. "Penggunaan Buku Cerita Anak: Berbasis Kearifan Lokal Mendong Tasikmalaya di Sekolah Dasar" dalam PEDADIDAKTIKA: Jurnal Ilmiah Pendidikan Guru Sekolah Dasar.Vol. 5, No. 2 (2018) 152-162

Brady, L. 1991. "Children and Their Books: The Right Book for The Right Child 1", dalam Maurice Saxby \& Gordon Winch (ed.). Give Them Wings, The Experience of Children's Literature, Melbourne: The Macmillan Company, hlm 26-38.

Keraf, A.S. 2010. Etika Lingkungan Hidup. Jakarta: Penerbit Buku Kompas.

Lickona, T. 1991. Educating for Character: How Our School Can Teach Respect and Responsibility, New York, Toronto, London, Sydney, Aucland: Bantam Books

Nurgiyantoro, B. 2005. "Tahapan Perkembangan Anak dan Pemilihan Bacaan Sastra Anak" dalam Cakrawala Pendidikan. Juni Tahun 2005, Th,XXiV. No 2.

Rampan, K. L. 2003. "Dasar-Dasar Penulisan Cerita Anak” dalam Teknik Menulis Cerita Anak, ed. Sabrur R. Soenardi. Yogyakarta: Pinkbook.

Ratih, R. 2016. "Menulis Cerita Anak: Menanam Kata Berbuah Karya" dalam Seminar HISKI BBY kerjasama dengan HISKI UAD.

Ratih, R. 2011. Sang Pembangkang. Yogyakarta: Pustaka pelajar

Ratih, R. 2013.Puteri Emas dan Burung Ajaib. Yogyakarta: Pustaka Pelajar.

Ratih, R. 2014. Putri Cantik dari Pulau Bintan. Yogyakarta: Pustaka Pelajar 
Ratih, R. 2015. Lebah Lebay di Taman Larangan. Yogyakarta: Pustaka Pelajar.

Ratih, R. 2017. Belalang Sembah dan Putri Lala. Yogyakarta: Azza grafika.

Ratih, R. 2018. Surti, Mawar, dan Кири-Кири. Yogyakarta: Buana Grafika.

Rahyono. F.X. 2009. Kearifan Budaya dalam Kata. Jakarta: Wedatama Widyasastra.

Prayitno, U. S. Kontekstualisasi Kearifan lokal dalam Pemberdayaan Masyarakat (Jakarta: Pusat Pengkajian, Pengolahan Data dan Informasi Sekretariat Jenderal DPR RI, 2013), hlm 59.

Sarumpaet, R. K. T. 2003. "Struktur Bacaan Anak" dalam Teknik Menulis Cerita Anak, ed. Sabrur R. Soenardi. Yogyakarta: Pinkbook.

Sternberg, R. J., Jarvin, Linda, Reznitskaya, Alina, Teaching for Wisdom Through History: Infusing Wise Thinking Skills in School Curriculum dalam Ferrari, Michel, Potworowski, Georges, Ed., Teaching for Wisdom: Cross-Cultural Perspective on Fostering Wisdom,, (Netherland: Springer, 2008). 